\title{
Effect of concentrate supplementation during the dry period on colostrum quality and effect of colostrum feeding regimen on passive transfer of immunity, calf health, and performance
}

\author{
A. Dunn, ${ }^{\star}$ A. Ashfield,† B. Earley,‡ M. Welsh,§ A. Gordon,† M. McGee,‡ and S. J. Morrison*1 \\ *Sustainable Livestock, Agri-food and Bio-sciences Institute, Hillsborough, United Kingdom, BT26 6DR \\ †Agri-food and Bio-sciences Institute, Newforge Lane, Belfast, United Kingdom, BT9 5PX \\ ¥Animal and Grassland Research and Innovation Centre (AGRIC), Teagasc, Grange, Dunsany, Co. Meath, Ireland, C15 PW93 \\ $\S$ Sisaf, Unit 15A Innovation Centre, Queen's Road, Belfast, United Kingdom, BT3 9DT
}

\section{ABSTRACT}

The objectives were to evaluate the effect of (1) supplementing concentrates to multiparous Holstein cows during the dry period on colostral and milk immunoglobulin G (IgG) concentration; and (2) feeding calves colostrum at either 5 or $10 \%$ of their body weight (BW) on passive transfer of immunity, health, and performance. Holstein multiparous cows $(\mathrm{n}=37)$ were assigned to 1 of 2 nutritional treatments during an 8-wk dry period: (1) offered ad libitum grass silage only (GS) or (2) offered ad libitum access to the same grass silage plus concentrate [total mixed ration in a $75: 25$ dry matter (DM) ratio], providing a mean concentrate DM intake of $3.0 \mathrm{~kg} / \mathrm{cow}$ per day (GSC). Both treatment groups were offered identical levels of mineral and vitamin supplementation. Calves from these cows were weighed immediately after birth and fed either $5 \%(5 \mathrm{BW})$ or $10 \%(10 \mathrm{BW})$ of their $\mathrm{BW}$ in colostrum from their own dams within $2.5 \mathrm{~h}$ of birth. Calves in the 10BW group received their second feed of colostrum from first-milking colostrum. Concentrate supplementation during the dry period had no effect on colostral IgG concentration, first-milking IgG yield, or fat, protein, and lactose contents. However, cows in GSC produced a greater mean milk yield over the first 8 milkings compared with cows in the GS group. Concentrate supplementation had no effect on calf BW or BW gain, serum IgG, or apparent efficiency of absorption (AEA) at $24 \mathrm{~h}$ after birth. However, offspring from the GSC group had fewer cases of enteritis during the first $56 \mathrm{~d}$ of life compared with offspring from the GS group. Calves in the 10BW group had greater mean serum IgG concentration for the first $3 \mathrm{~d}$ following birth; however, at $24 \mathrm{~h}$ after birth, we observed no treatment effect on AEA. The rate of enteritis was greater for calves in the

Received April 19, 2016.

Accepted September 30, 2016.

${ }^{1}$ Corresponding author: Steven.Morrison@afbini.gov.uk
5BW treatment compared with 10BW. The colostrumfeeding regimen had no effect on BW gain or on the incidence of pneumonia among calf treatment groups. In conclusion, concentrate supplementation regimens offered during the dry period had a positive effect on colostrum yield, and offspring from the GSC group had a reduced rate of enteritis. Feeding $10 \%$ of BW of colostrum versus $5 \%$ of BW resulted in a greater serum IgG concentration for the first $3 \mathrm{~d}$ postpartum, and 10BW calves had a reduced rate of enteritis. Overall, to achieve successful passive transfer, decrease the rate of enteritis, and increase efficiency in the dairy calf, we recommend that dairy calves be fed $10 \%$ of their BW in colostrum as soon as possible after birth.

Key words: calf, colostrum, concentrate, dry period, immunoglobulin G

\section{INTRODUCTION}

Bovine colostrum is the primary source of nutrients and immunity for the newborn calf (Quigley and Drewry, 1998). The process of colostrogenesis takes place several weeks before parturition; during this time, immunoglobulins are transferred from the dam's circulation into mammary secretions and subsequently the transfer of Ig ceases immediately before parturition (Brandon et al., 1971; Barrington and Parish, 2001). Previous research has focused primarily on dietary and management strategies for beef cows during their dry period on colostrum quality (Blecha et al., 1981; Hough et al., 1990; McGee et al., 2006). However, limited data are available for the dairy cow and the effect these strategies have upon their offspring (Funston et al., 2010; Nowak et al., 2012). Studies have been conducted on beef cows to investigate the effects of protein and energy restrictions (Blecha et al., 1981; Hough et al., 1990) on colostrum quality. However, further research is required because dairy cows face different metabolic challenges during the peripartum period compared with beef cows (Mann et al., 2016). 
The bovine dam has a syndesmochorial placenta, which prevents transmission of antibodies to the unborn calf while it is in the uterus (Weaver et al., 2000). Therefore, the calf is born agammaglobulinemic and is solely dependent on colostrum for the passive transfer of immunoglobulins, immune cells (Barrington and Parish, 2001), and for nutrients that only minimally cross the placenta such as fat-soluble vitamins (Spielman et al., 1946). Immunoglobulins are proteins that are produced in reaction to stimulation by antigens and that later destroy those antigens (Murphy et al., 2005). The transfer of passive immunity from cow to calf via colostrum is considered adequate when the IgG concentration in the serum of the calf exceeds $10 \mathrm{mg} /$ $\mathrm{mL}$ in the first few days after birth (Godden, 2008; Logue and Mayne, 2014). Successful passive transfer has been related to lower veterinary costs during the preweaning stage, enhanced weight gain, improved performance, and prolonged existence in the milking herd (Weaver et al., 2000; Faber et al., 2005; Lorenz et al., 2011). However, recent findings from the All-Island Animal Disease Surveillance Report (AFBI-DAFM, 2013) showed $56 \%$ of calves to have undergone failure of passive transfer (FPT) based on blood samples submitted by private veterinary practitioners and on samples from dead calves submitted for postmortem. Several studies have examined the effect of colostrum volume on passive transfer of immunoglobulins, and recommendations on the volume of colostrum to feed to the newborn calf vary between breeds (Jaster, 2005; Conneely et al., 2014). Chigerwe et al. (2008) recommended that Holstein-Friesian calves of normal size should be fed $3 \mathrm{~L}$ of high-quality (IgG $>50 \mathrm{mg} / \mathrm{mL}$; McGuirk and Collins, 2004) colostrum via esophageal tube within $2 \mathrm{~h}$ of life. Jaster (2005) found that Jersey calves fed $2 \mathrm{~L}$ of good quality colostrum at 0 and $12 \mathrm{~h}$ had higher serum $\operatorname{IgG}_{1}$ levels at $24 \mathrm{~h}$ than calves fed 4 $\mathrm{L}$ of colostrum at birth. Recent research has focused on feeding colostrum in a volume based on a percentage of BW (Conneely et al., 2014). In most dairy systems, the calf is removed from the dam immediately after birth, fed colostrum, and offered milk replacer or whole milk thereafter until weaning. Recently it has become popular to house calves in groups during the preweaning period; consequently, it is more difficult to detect disease (Chua et al., 2002), and the spread of disease is more frequent compared with that among individually penned calves. However, calves in group pens are generally fed via automated feeders, and feeding behavior can be recorded. This may be a useful tool for identifying sick calves in the early stages and can allow for early treatment (Borderas et al., 2009).

The objectives of this study were to investigate the effect of concentrate supplementation of dams during the nonlactating period of approximately $8 \mathrm{wk}$ on colostrum quality and yield and subsequent calf health and performance when fed different levels of colostrum according to BW.

\section{MATERIALS AND METHODS}

All procedures and treatments within this study were conducted under the United Kingdom Animals (Scientific Procedures) Act (1986; http://www.legislation.gov.uk/ukpga/1986/14/contents). The study was conducted at the Agri-Food and Bioscience Institute (AFBI) research dairy farm in Hillsborough, located in County Down, Northern Ireland $\left(54^{\circ} 27^{\prime} \mathrm{N}, 6^{\circ} 4^{\prime} \mathrm{W}\right)$. The average $( \pm \mathrm{SD})$ daily air temperature during the experiment was $6.9^{\circ} \mathrm{C}$, with a range of -0.5 to $13.4^{\circ} \mathrm{C}$. The study population consisted of 37 multiparous Holstein cows that calved between February 9 and April 17,2014 . The mean $( \pm \mathrm{SD})$ birth weight of calves was $40.4 \pm 6.2 \mathrm{~kg} ; 19$ of these calves were female and 18 were male.

\section{Experimental Design}

The experiment had a $2 \times 2$ factorial design, which included 2 dry-cow feeding treatments: (1) grass silage only (GS) or (2) grass silage plus concentrate (GSC), offered in the form of a mixed diet providing a nominal concentrate intake of approximately $3 \mathrm{~kg} / \mathrm{cow}$ per day; and 2 first-feed colostrum treatments fed according to calf BW at birth: (1) $5 \%$ of BW of colostrum at birth (5BW) or (2) $10 \%$ of $\mathrm{BW}$ of colostrum at birth $(\mathbf{1 0 B W})$. Colostrum was defined as the first and second milkings after parturition, and transition milk referred to any subsequent milkings.

\section{Dry-Cow Management}

Cows were balanced according to BCS, previous 305-d milk yield, and parity (Little et al., 2016). Dry cows in the GS group received access to ad libitum medium-quality grass silage only, whereas cows in the GSC group were offered ad libitum access to a mixed diet containing the same medium-quality grass silage plus concentrates (mixed in a 75:25 DM ratio), which was intended to provide an average concentrate intake of approximately $3.0 \mathrm{~kg} / \mathrm{cow}$ per day (Little et al., 2016). These diets were anticipated to be representative of typical UK on-farm management strategies and to offer approximately 100 and $130 \%$ of the cow's ME requirement during the dry period (ME intake of 106 and $138 \mathrm{MJ} / \mathrm{d}$ with the GS and GSC treatments, respectively), based on the equations contained in Feed into Milk (Agnew et al., 2004), the current UK ration- 
Table 1. Chemical composition of dry-cow diet

\begin{tabular}{|c|c|c|}
\hline \multirow[b]{2}{*}{ Chemical composition } & \multicolumn{2}{|c|}{ Treatment $^{1}$} \\
\hline & GS & GSC \\
\hline Oven DM ( $\mathrm{g} / \mathrm{kg}$ of fresh weight) & 233 & 883 \\
\hline $\operatorname{VCODM}^{2}(\mathrm{~g} / \mathrm{kg})$ & 242 & - \\
\hline $\mathrm{pH}$ & 3.89 & - \\
\hline Ammonia- $\mathrm{N}(\mathrm{g} / \mathrm{kg}$ of total $\mathrm{N})$ & 106 & - \\
\hline \multicolumn{3}{|l|}{ Composition of DM $(\mathrm{g} / \mathrm{kg})$} \\
\hline $\mathrm{CP}$ & 148 & 187 \\
\hline Lactic acid & 105.0 & - \\
\hline Acetic acid & 23.8 & - \\
\hline $\mathrm{ADF}$ & 329 & 73 \\
\hline $\mathrm{NDF}$ & 556 & 215 \\
\hline Ash & 107 & 36 \\
\hline Gross energy (MJ/kg of DM) & 19.3 & 18.3 \\
\hline $\mathrm{ME}(\mathrm{MJ} / \mathrm{kg}$ of $\mathrm{DM})$ & $10.5^{3}$ & - \\
\hline
\end{tabular}

${ }^{1}$ Treatments: GS $=$ grass silage only; GSC $=$ grass silage plus concentrate.

${ }^{2} \mathrm{VCODM}=$ volatile-corrected oven DM.

${ }^{3}$ Predicted using near-infrared reflectance spectroscopy.

ing system for dairy cows. Chemical composition of the silage and concentrate offered are shown in Table 1. The ingredient content of the concentrate offered ( $\mathrm{g} /$ $\mathrm{kg}$ fresh basis) included soy hulls, $300 \mathrm{~g} / \mathrm{kg}$; corn, 238 $\mathrm{g} / \mathrm{kg}$; wheat, $127 \mathrm{~g} / \mathrm{kg}$; corn gluten, $150 \mathrm{~g} / \mathrm{kg}$; soybean meal, $80 \mathrm{~g} / \mathrm{kg}$; rapeseed meal, $70 \mathrm{~g} / \mathrm{kg}$; and Molaferm (United Molasses, Belfast, UK) $35 \mathrm{~g} / \mathrm{kg}$. During the 8-wk dry period, all cows received a dry-cow mineral and vitamin supplement (Trouw Nutrition, Cheshire, UK), which was included in the mix to achieve a target intake of $100 \mathrm{~g} / \mathrm{cow}$ per day. In addition, $54 \mathrm{~g} / \mathrm{d}$ of calcined magnesite (Trouw Nutrition) was included in the mix to achieve a target of $50 \mathrm{~g} / \mathrm{d}$ of DM in the last $3 \mathrm{wk}$ precalving (Little et al., 2016). Dry-cow rations were prepared daily using a mixer wagon (Redrock Varicut, Redrock, UK). As parturition approached, cows were moved from a group pen into individual straw-bedded pens.

\section{Management of Calves}

The birth of each calf was carefully observed and calves were removed approximately 15 to 20 min after parturition before suckling could occur. Calves were weighed and placed in a straw-bedded pen, where they were blood sampled and received their first feed of colostrum, according to the colostrum treatment group to which they were assigned. Each calf was randomly assigned to a colostrum treatment group depending on dry-cow nutrition status and calf sex, and fed their own dam's colostrum via esophageal tube within $2.5 \mathrm{~h}$ after birth. Cows in all treatment groups were given $5 \%$ of their BW of colostrum (from their own dam) at their second feeding via a teat feeder, $12 \mathrm{~h}$ after calving. Calves in the 10BW group received colostrum from the first milking after birth (stored at $4^{\circ} \mathrm{C}$ and heated to body temperature before feeding), whereas calves in the $5 \mathrm{BW}$ group were fed colostrum from the second milking. These experimental diets were designed to create a divergence in immunity between treatment groups (colostrum from the second milking generally has a lower $\operatorname{IgG}$ concentration than colostrum from first milking). Following the first and second colostrum feeds, all calves were fed $12.5 \%$ of their BW of transition milk from their own dam for the first $4 \mathrm{~d}$ of life. Calves were individually penned for the first $4 \mathrm{~d}$ of life, and were placed in a group pen on d 5, where they were fed Calf Gold milk replacer (Britmilk, Dumfries, UK) from an automatic milk feeder (Forster Technik Vario, Engen, Germany). Calves were gradually weaned (d 56) by the step-down method, and the feeding plan is shown in Table 2.

All calves were offered ad libitum concentrate and clean water from $5 \mathrm{~d}$ of age. Disbudding of calves took place at approximately 5 to 6 wk of age. After weaning, calves were removed from their original pen to another group pen on d 63 and fed grass silage plus $2 \mathrm{~kg}$ of

Table 2. Feeding plan for colostrum/transition milk and milk replacer (e.g., for 40-kg calf)

\begin{tabular}{lllll}
\hline & \multicolumn{2}{c}{ Colostrum treatment $(\mathrm{L})$} & & \\
\cline { 2 - 3 } Age $(\mathrm{d})$ & $5 \%$ of BW & $10 \%$ of BW & No. of feeds/d & Milk powder ${ }^{1}(\mathrm{~g} / \mathrm{L})$ \\
\hline 0 & 2 (first milk colostrum) & 4 (first milk colostrum) & 1 & - \\
0.5 & 2 (second milk colostrum) & 2 (first milk colostrum) & 1 & - \\
1 & 4.8 (transition milk) & 4.8 (transition milk) & 2 & - \\
2 & 4.8 (transition milk) & 4.8 (transition milk) & 2 & - \\
3 & 4.8 (transition milk) & 4.8 (transition milk) & 2 & 135 \\
4 & 4.8 (transition milk) & 4.8 (transition milk) & 2 & 135 \\
$5-10$ & 4 increasing to 5 & 4 increasing to 5 & Automatic feeder & \\
$12-38$ & 5 & 5 & Automatic feeder & 125 \\
$39-49$ & 4 & 4 & Automatic feeder & 125 \\
$50-56$ & 4 decreasing to 2 & 4 decreasing to 2 & Automatic feeder & \\
\hline
\end{tabular}

${ }^{1}$ Milk powder was mixed with $1 \mathrm{~L}$ of water; that is, $1 \mathrm{~L}$ of water +135 or $125 \mathrm{~g}$ of milk powder depending on age of calf. 
concentrate/d until $70 \mathrm{~d}$ of age, when the experiment was complete.

All calves in the study were immunized at $3 \mathrm{wk}$ of age against parainfluenza type 3 virus, bovine respiratory syncytial virus, and Mannheimia (Pasteurella) haemolytica serotype A1 using a commercial vaccine (Bovipast RSP, MSD Animal Health, Buckinghamshire, UK), and a booster was administered 4 wk later. All calves were also immunized against infectious bovine rhinotracheitis (IBR), using 1 dose of a live commercial vaccine (Bovilis IBR marker, MSD Animal Health, Milton Keynes, UK), which was administered intranasally at $6 \mathrm{wk}$ of age.

\section{Data Collection}

Colostrum and Blood Sample Collection. Colostrum yield was recorded for the first 8 milkings after parturition; two $200-\mathrm{mL}$ samples were taken after yield was recorded. Samples were divided into eight $30-\mathrm{mL}$ aliquots and frozen at $-20^{\circ} \mathrm{C}$ for later analysis. Colostrum samples from milkings $1,3,5$, and 7 were analyzed for IgG concentration, fat, protein, lactose, total viable count (TVC), and SCC. Blood samples were collected from the tail vein of cows using a 10-mL serum Vacutainer (BD, Oxford, UK) at wk $-5,-3,-1$ precalving and +2 wk postcalving. Blood samples were collected from the calf via the jugular vein using a $10-\mathrm{mL}$ serum Vacutainer tube (BD), at $0,12,24,48$, and $72 \mathrm{~h}$ after birth and d 7, 21, 35, 49, 56 and 70 after birth. A blood sample was taken from calves before colostrum intake at $0 \mathrm{~h}$ and subsequently before the second colostrum feed at $12 \mathrm{~h}$ and the third feed at $24 \mathrm{~h}$ after birth. All other blood sampling was performed between 0900 and $1030 \mathrm{~h}$. All blood samples were stored at room temperature for a minimum of $1 \mathrm{~h}$ to allow clotting to occur. Samples were then centrifuged at $1,764 \times g$ for $15 \mathrm{~min}$. Serum was decanted into 3 aliquots and stored at $-20^{\circ} \mathrm{C}$ until analysis.

Health Data. Daily respiratory scores were conducted using a health scoring chart (McGuirk and Peek, 2014). Calves were scored on 5 aspects from d 0 to 56 including eyes, ears, cough, nasal discharge, and rectal temperature. Each aspect received a score from 0 to 3, 0 representing normal and 3 the most severely affected. Rectal temperatures were taken daily using a digital thermometer (Kruuse, Leeds, UK). A respiratory score was devised from the cumulative score from nasal discharge, eye or ear score, cough, and rectal temperature. A calf was considered to have a bovine respiratory disease (BRD) complex event if it had a respiratory score $\geq 5$. Fecal scores were measured daily on a scale of 0 to 3 , where $0=$ normal, $1=$ mild, 2
$=$ moderate, and $3=$ severe. When a calf presented with a fecal score of 3 or had a fecal score of 2 for 2 or more days, it was considered to have enteritis. The number of drug treatments for each calf was recorded, and a treatment was classified as each time a drug was administered to a calf (i.e., a calf might receive a 3-d course of antibiotics for diarrhea; this was counted as 3 treatments. Calf ill health was defined in this study when a calf was presenting with diarrhea, pneumonia, or high temperature; an overall daily score was calculated using the Wisconsin scoring chart (McGuirk and Peek, 2014), and the calf was considered healthy at a score $<5$ (Borderas et al., 2009).

Feed Intake and Behavior. Milk replacer and concentrate intakes were recorded daily by a calibrated automatic feeder (Forster Technik Vario) from d 5 to 56 and from d 5 to 63 , respectively. Calf behavioral data were recorded, including drinking speed and number of visits to the feeder with and without the reward of milk replacer.

$\boldsymbol{B} \boldsymbol{W}$. Calves were weighed at birth and d 70 using a calibrated weigh scale (Eziweigh 5, Tru-Test, Auckland, New Zealand). Once calves were introduced to the automatic feeder on d 5, their weights were recorded daily using an automated weigh scale until d 63 (Forster Technik).

\section{Sample Analysis}

Colostrum and Serum IgG Analysis. Colostrum and serum (dam and calf) samples were thawed at $4^{\circ} \mathrm{C}$ overnight. Immunoglobulin $\mathrm{G}$ concentration was analyzed using an ELISA kit for bovine IgG from Bio-X Diagnostics (Jemelle, Belgium). The test was performed on colostrum (fat was removed through centrifuging before freezing; colostrum IgG data were reported on a fat-free basis) and sera samples. All kit components were brought to $21^{\circ} \mathrm{C}$ before use. The wash buffer was diluted 20-fold with distilled water. A calibration curve was developed and samples were diluted at 1/1,000 in PBS according to the manufacturer's instructions. Diluted samples were added to the test plate in duplicate and incubated at $21^{\circ} \mathrm{C}$ for $1 \mathrm{~h}$. The test plate was then washed 3 times with the wash buffer; chromogen solution $(100 \mu \mathrm{L})$ was added to each well and incubated away from light for approximately $10 \mathrm{~min}$. Finally, stop solution $(50 \mu \mathrm{L})$ was added to each well and the optical densities were recorded using a microplate spectrophotometer with a $450-n m$ filter. An interassay CV of $<0.15$ was observed. The concentration of IgG in samples was calculated from the standard reference curve containing known concentrations of $\operatorname{IgG}$ provided in the test kit. Any sample that resulted in an IgG concentration that 
Table 3. Chemical composition of diet fed to calves during the preweaning period

\begin{tabular}{lccc}
\hline & \multicolumn{3}{c}{ Calf diet } \\
\cline { 2 - 4 } Chemical composition & $\begin{array}{c}\text { Milk } \\
\text { replacer }\end{array}$ & Concentrate & Straw \\
\hline Oven DM (g/kg of fresh weight) & 972 & 916 & 882 \\
Composition of DM (g/kg) & & & \\
Nitrogen & 36.6 & 29.6 & 5.7 \\
NDF & - & 347.5 & 869.3 \\
ADF & - & 175.9 & 530.5 \\
Ash & 201.9 & 75.4 & 47.3 \\
Ether extract & 22.8 & 18.4 & 13.9 \\
CP (\%) & - & 18.5 & 3.6 \\
Gross energy (MJ/kg of DM) & - & 18.5 \\
\hline
\end{tabular}

fell above or below the range of the standard reference curve was retested after further dilution according to the test kit recommendations.

Nutritional Composition and Bacterial Contamination of Colostrum and Milk. Colostrum/ transitional milk fat, protein, and lactose contents were determined using the Milkoscan technique (model FT120, Foss Electric, Hillerød, Denmark). Only samples that could be processed within $24 \mathrm{~h}$ of calving were analyzed for TVC and SCC $(\mathrm{n}=152)$. The TVC was determined by pour-plate method (Clark, 1967) and colonies were counted using a Stuart colony counter (Bibby Scientific Ltd., Stone, UK). The SCC of colostrum samples was analyzed using the Delta Somascope Lactoscope method (Delta Instruments, Drachten, the Netherlands) as described by Hanuš et al. (2014).

Dry-Cow Feed Analysis. Chemical composition of feedstuffs offered to dry cows is presented in Table 2. Grass silage samples were collected daily, dried at $85^{\circ} \mathrm{C}$ for $18 \mathrm{~h}$ to calculate oven DM content, and milled through a sieve (0.8-mm aperture). Every $2 \mathrm{wk}$, subsamples of the dried milled silages (collected twice weekly) were composited, and then analyzed for NDF, $\mathrm{ADF}$, and ash. A sample of the fresh silage offered was collected weekly and analyzed for ME concentration, and a second fresh sample was analyzed for $\mathrm{pH}$, gross energy, CP (nitrogen $\times 6.25$ ), ammonia-nitrogen, and fermentation acid (lactic acid and acetic acid) concentrations. To alter the oven DM of grass silage to a volatile-corrected DM basis, volatility coefficients were used. Once a week, a concentrate sample was collected, dried at $100^{\circ} \mathrm{C}$ for $24 \mathrm{~h}$ before milling through a sieve $(0.8 \mathrm{~mm})$, and composited every $2 \mathrm{wk}$. A subsample of concentrate was analyzed for NDF, ADF, ash, gross energy, and CP (nitrogen $\times 6.25)$ concentrations (Little et al., 2016). The NDF and ADF concentrations were analyzed using a Fibertec analyzer (Fibertec FT122, Foss) based on the method by Cushnahan and Gordon
(1995). Ash concentrations were established following combustion in a muffle furnace at $550^{\circ} \mathrm{C}$ for approximately $10 \mathrm{~h}$. Near-infrared reflectance spectroscopy was used to determine the ME concentration according to Park et al. (1998), and a bomb calorimeter was used to quantify gross energy concentration (Parr 6300 Bomb Calorimeter, Parr Instrument Co., Moline, IL). The Kjeldahl method (Tecator Kjeltec Auto 2400/2460 Analyzer/Sampler System, Foss) was used to analyze nitrogen concentration and ammonia-nitrogen as described by Steen (1989). Lactic acid and acetic acid concentrations were analyzed using single-column GLC with a flame-ionization detector (Varian Star 3400 CX GC, Varian Inc., Palo Alto, CA). Volatility coefficients were applied according to Porter and Murray (2001).

Calf Diet Analysis. Samples of milk replacer, starter ration, and straw bedding consumed by the calf were collected daily and bulked for each 2 -wk period throughout the experiment. Chemical composition of feedstuffs is presented in Table 3. Milk replacer, concentrate, and straw were analyzed for oven DM, and the dried samples were analyzed for nitrogen as previously described by Steen (1989). The ADF and NDF concentrations were determined using a Fibertec analyzer (Fibertec FT122, Foss) based on the method by Cushnahan and Gordon (1995), and ash concentrations were determined following combustion in a muffle furnace at $550^{\circ} \mathrm{C}$ for approximately $10 \mathrm{~h}$. Concentrate and straw samples were analyzed for gross energy (Porter, 1992).

Apparent Efficiency of Absorption. The apparent efficiency of absorption (AEA) was determined in this study to determine how much IgG the calves in each treatment group absorbed into their blood before closure of the gut at $24 \mathrm{~h}$. The method used to calculate plasma volume was as described by Quigley et al. (1998): plasma volume $=$ calf BW $(\mathrm{kg})$ multiplied by 0.089. Data used to calculate the AEA was the 24-h serum IgG concentration and total IgG mass fed in the first $24 \mathrm{~h}$ [feed $1(0 \mathrm{~h})$ and feed $2(12 \mathrm{~h})$ ]. The following formula was used to calculate the AEA (Quigley, 2002):

$$
\mathrm{AEA}=[\operatorname{serum} \operatorname{IgG}(\mathrm{mg} / \mathrm{mL})
$$

$\times$ plasma volume $(\mathrm{L}) /$ total $\operatorname{IgG}$ intake $(\mathrm{mg})] \times 100$.

\section{Statistical Analysis}

Statistical analyses were performed using GenStat (16th ed., 2015; VSN International, Hemel Hempstead, UK). Statistical differences were considered significant at $P<0.05$. Repeated measures were used to analyze daily milk replacer and concentrate DMI, and drinking speed. Individual calf and days on feeder were fitted as 
Table 4. Effect of concentrate supplementation and colostrum feeding regimen on birth weight, colostrum intake, colostral IgG concentration and yield, and apparent efficiency of absorption (AEA)

\begin{tabular}{|c|c|c|c|c|c|c|c|c|}
\hline Item & \multicolumn{2}{|c|}{ Dry-cow treatment ${ }^{1}$} & \multicolumn{2}{|c|}{ Colostrum treatment } & $\mathrm{SED}^{2}$ & \multicolumn{3}{|c|}{ Significance $^{3}$} \\
\hline Birth weight $(\mathrm{kg})$ & 40.1 & 40.7 & 39.9 & 40.9 & 2.14 & 0.77 & 0.64 & 0.53 \\
\hline First colostrum $\operatorname{IgG}(\mathrm{mg} / \mathrm{mL})$ & 55.2 & 53.3 & 58.8 & 49.7 & 7.17 & 0.64 & 0.27 & 0.03 \\
\hline IgG yield at first milking (g) & 390.0 & 365.0 & 381.0 & 374.0 & 58.88 & 0.50 & 1.00 & 0.06 \\
\hline $\mathrm{AEA}$ at $24 \mathrm{~h}(\%)$ & 28.2 & 32.0 & 26.4 & 33.9 & 5.44 & 0.24 & 0.22 & 0.05 \\
\hline
\end{tabular}

${ }^{1}$ Dry-cow treatments: GSC $=$ grass silage plus concentrate; GS = grass silage only.

${ }^{2} \mathrm{SED}=\mathrm{SE}$ of the difference.

${ }^{3} \mathrm{~N}=$ nutrition during dry period; $\mathrm{V}=$ volume of colostrum fed; $\mathrm{N} \times \mathrm{V}=$ interaction of nutrition and volume fed.

random effects in the model and a factorial arrangement of calf age, dry-cow treatment, and colostrum feeding regimens as fixed effects. The correlation between time points was modeled using autoregressive model of order 1. Colostrum yields and colostrum IgG concentration used the same form of model except different correlation models were used, ante dependence correlation and autoregressive correlation, respectively. Covariates included minutes after calving and sex, with only significant covariates retained in the final model for each response variable. A generalized linear model (GLM) was used to analyze any count variables, such as total number of drug treatments, and medical treatments. Fecal scores were analyzed using Poisson distribution with a logarithmic link function. Dry-cow treatments and colostrum feeding regimen as fixed effects, and dry-cow nutrition and colostrum feeding regimen were fitted as explanatory variables when analyzing fecal score. Total mean respiratory scores (rectal temperature, cough, nasal discharge, eyes, ears) and mean fecal scores were analyzed using the REML commands with a factorial arrangement of dry-cow nutrition and firstfeed colostrum fitted as fixed effects. Body weight gain was analyzed using the same model, including birth weight as a covariate. The REML commands with a factorial arrangement were also used to analyze serum IgG and AEA of IgG at $24 \mathrm{~h}$ and feed efficiency preweaning. A factorial arrangement was fitted as fixed effects and calf was fitted as a random effect. When relevant, post hoc tests were carried out using Fisher's protected least significant difference test.

\section{RESULTS}

Concentrate supplementation had an effect $(P=$ $0.004)$ on IgG concentration circulating in the dam's blood pre- and postparturition: on average, cows in the GSC group had a greater mean $( \pm \mathrm{SE})$ serum IgG $(38.5 \pm 2.1 \mathrm{mg} / \mathrm{mL})$ concentration than cows in the GS group $(26.6 \pm 0.75 \mathrm{mg} / \mathrm{mL}$; Figure 1$)$. Time pre- and postparturition did not significantly affect IgG concentration.

Calf birth weight was not significantly different between treatment groups (Table 4). The time at which calves received their first colostrum feed ranged from $10 \mathrm{~min}$ to $2.5 \mathrm{~h}$ after calving; on average, calves in each treatment group were fed within $1 \mathrm{~h}$. The mean colostrum intake volume at the first feed for $5 \mathrm{BW}$ and $10 \mathrm{BW}$ calves was $1.9 \mathrm{~L}(1.4$ to $2.0 \mathrm{~L})$ and $3.8 \mathrm{~L}(2.6$ to $4.0 \mathrm{~L})$, respectively. The mean colostrum intake at the second feed (12 h after birth) for 5BW and 10BW calves was $1.9 \mathrm{~L}(1.35$ to $2 \mathrm{~L})$ and $1.9 \mathrm{~L}(1.3$ to $2 \mathrm{~L})$, respectively. The mean $( \pm \mathrm{SD})$ colostral IgG concentration fed to $5 \mathrm{BW}$ and 10BW calves at the second feed was $51.9 \pm$ 27.77 and $54.0 \pm 27.63 \mathrm{mg} / \mathrm{mL}$, respectively.

We observed no difference in AEA at $24 \mathrm{~h}$ after birth between 5BW and 10BW calves, and concentrate supplementation had no effect on AEA (Table 4).

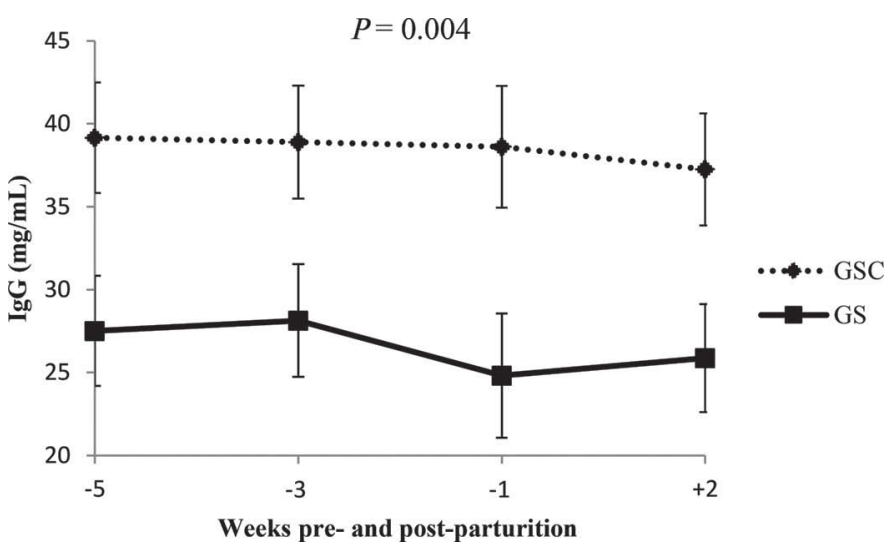

Figure 1. Effect of concentrate supplementation on dam's serum IgG concentration pre- and postparturition. Error bars represent standard error of the mean. GSC = grass silage plus concentrate; GS = grass silage only. 
Table 5. Effect of dry cow treatment ${ }^{1}$ on colostrum/transitional milk yields for first 8 milkings postparturition (1 to 8 )

\begin{tabular}{|c|c|c|c|c|}
\hline \multirow{2}{*}{$\begin{array}{l}\text { Milking } \\
\text { no. }\end{array}$} & \multicolumn{2}{|c|}{$\begin{array}{l}\text { Colostrum/transition } \\
\text { milk yield }(\mathrm{kg})\end{array}$} & \multirow[b]{2}{*}{ SD } & \multirow[b]{2}{*}{$P$-value } \\
\hline & GS & GSC & & \\
\hline 1 & 7.10 & 7.48 & 0.26 & $<0.001$ \\
\hline 2 & 3.80 & 4.87 & 0.76 & \\
\hline 3 & 5.98 & 7.21 & 0.87 & \\
\hline 4 & 7.99 & 11.42 & 2.43 & \\
\hline 5 & 8.91 & 10.70 & 1.27 & \\
\hline 6 & 9.89 & 13.13 & 2.29 & \\
\hline 7 & 10.24 & 11.06 & 0.58 & \\
\hline 8 & 11.95 & 14.16 & 1.56 & \\
\hline
\end{tabular}

${ }^{1}$ Dry-cow treatments: GSC $=$ grass silage plus concentrate; $\mathrm{GS}=$ grass silage only.

\section{Colostrum Yield and Quality}

Cows in the GSC group produced a greater yield of colostrum than cows in the GS group $(P<0.001$; Table $5)$. Concentrate supplementation did not affect colostral IgG concentration, IgG yield, or concentrations of fat, protein, or lactose. Concentrate supplementation in the dry period did not affect $(P>0.05)$ SCC or TVC. We found mean colostral SCC of $\log _{10} 2.8$ and 2.9 from cows in GSC and GS groups, respectively, and mean TVC of $\log _{10} 5.3$ and 5.2 , respectively, from the first 8 milkings postparturition.

\section{Time from Calving to Colostrum Collection}

Increased time from calving until colostrum collection was associated with a significant decrease $(P$ $<0.001)$ in colostral IgG concentration, as shown in Figure 2. Between d 1 (milking 1) and d 2 (milking 3) postcalving, there was a $56 \%$ decrease in colostrum or milk IgG concentration.

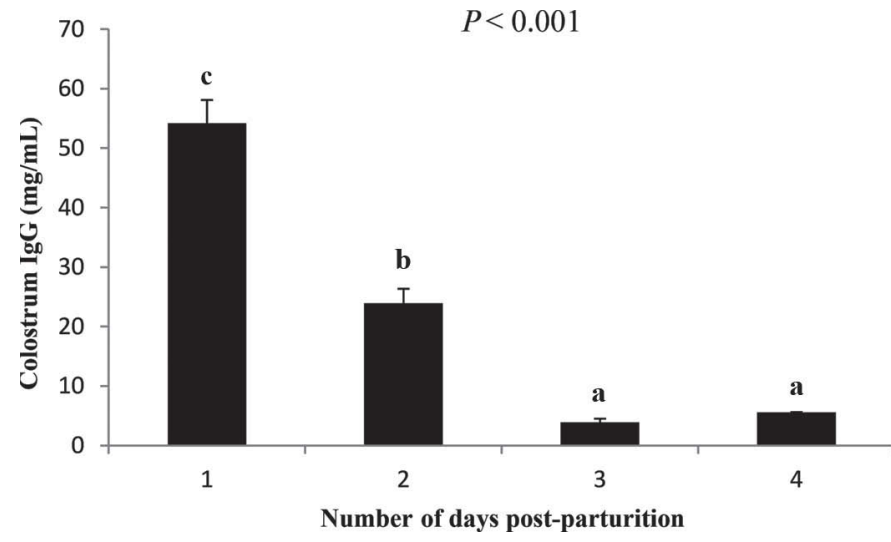

Figure 2. Effect of the number of days postcalving on colostrum IgG concentrations. Means within bars with different letters $(\mathrm{a}-\mathrm{c})$ differ $(P<0.05)$. Error bars represent standard error of the mean.

\section{Calf Serum IgG Concentration}

Volume of colostrum fed at the first feed had an effect $(P<0.05)$ on calf serum IgG concentration during the first $3 \mathrm{~d}$ after birth, as shown in Table 6 . Concentrate supplementation had no effect on calf serum $\operatorname{IgG}$ concentration.

\section{Milk Replacer and Concentrate Intake}

Neither concentrate supplementation nor colostrum feeding regimen affected $(P>0.05)$ milk replacer intake (Table 7). Concentrate supplementation during the dry period had no significant effect on the calves' concentrate intake. Calves in treatment 5BW consumed more concentrate than calves in treatment $10 \mathrm{BW}$ during d 5 to $28(P=0.04)$ and we observed a strong tendency for greater consumption from d 5 to $56(P=0.05$; Table

Table 6. Effect of concentrate supplementation and colostrum feeding regimen on calf serum $\operatorname{IgG}(\mathrm{mg} / \mathrm{mL})$ from 0 to $70 \mathrm{~d}$ of age

\begin{tabular}{|c|c|c|c|c|c|c|c|c|}
\hline \multirow{2}{*}{$\begin{array}{l}\text { Time after } \\
\text { birth (d) }\end{array}$} & \multicolumn{2}{|c|}{ Dry-cow treatment $^{1}$} & \multicolumn{2}{|c|}{ Colostrum treatment } & \multirow[b]{2}{*}{$\mathrm{SED}^{2}$} & \multicolumn{3}{|c|}{ Significance $^{3}$} \\
\hline & GSC & GS & $5 \%$ of $\mathrm{BW}$ & $10 \%$ of $\mathrm{BW}$ & & $\mathrm{N}$ & $\mathrm{V}$ & $\mathrm{N} \times \mathrm{V}$ \\
\hline 0 & 0.7 & 0.8 & 0.7 & 0.8 & 0.08 & 0.16 & 0.23 & 0.96 \\
\hline 0.5 & 18.4 & 17.3 & 14.6 & 21.1 & 2.16 & 0.60 & 0.004 & 0.94 \\
\hline 1 & 18.1 & 17.0 & 14.1 & 20.9 & 2.43 & 0.58 & 0.008 & 0.73 \\
\hline 2 & 20.8 & 20.7 & 16.6 & 24.9 & 3.93 & 0.85 & 0.04 & 0.84 \\
\hline 3 & 14.6 & 15.8 & 13.4 & 17.0 & 1.55 & 0.56 & 0.02 & 0.90 \\
\hline 7 & 11.0 & 11.0 & 9.8 & 12.2 & 1.42 & 0.96 & 0.09 & 0.74 \\
\hline 21 & 7.0 & 7.8 & 6.6 & 8.2 & 1.07 & 0.48 & 0.15 & 0.88 \\
\hline 35 & 7.6 & 11.6 & 8.9 & 10.3 & 1.43 & 0.02 & 0.19 & 0.01 \\
\hline 49 & 12.5 & 10.8 & 12.3 & 11.0 & 1.38 & 0.30 & 0.35 & 0.12 \\
\hline 56 & 19.7 & 18.0 & 18.7 & 19.0 & 2.61 & 0.57 & 0.93 & 0.32 \\
\hline 70 & 12.6 & 12.3 & 12.1 & 12.9 & 1.51 & 0.83 & 0.56 & 0.87 \\
\hline
\end{tabular}

${ }^{1}$ Dry-cow treatments: GSC = grass silage plus concentrate; GS = grass silage only.

${ }^{2} \mathrm{SED}=\mathrm{SE}$ of the difference.

${ }^{3} \mathrm{~N}=$ nutrition during dry period; $\mathrm{V}=$ volume of colostrum fed; $\mathrm{N} \times \mathrm{V}=$ interaction of nutrition and volume fed. 
Table 7. Effect of concentrate supplementation and colostrum feeding regimens on feed intake and behavioral data of calves

\begin{tabular}{|c|c|c|c|c|c|c|c|c|}
\hline Item & \multicolumn{2}{|c|}{ Dry-cow treatment ${ }^{1}$} & \multicolumn{2}{|c|}{ Colostrum treatment } & $\mathrm{SED}^{2}$ & \multicolumn{3}{|c|}{ Significance $^{3}$} \\
\hline d $5-56$ & 4.18 & 4.24 & 4.22 & 4.19 & 0.05 & 0.20 & 0.56 & 0.84 \\
\hline d $5-28$ & 4.48 & 4.60 & 4.52 & 4.56 & 0.07 & 0.12 & 0.63 & 0.57 \\
\hline d 29-56 & 3.92 & 3.93 & 3.97 & 3.88 & 0.07 & 0.75 & 0.21 & 0.95 \\
\hline Drinking speed (mL/min) & 840.00 & 896.00 & 853.00 & 883.00 & 37.95 & 0.24 & 0.26 & 0.99 \\
\hline d $5-28$ & 0.08 & 0.08 & 0.1 & 0.06 & 0.02 & 0.86 & 0.04 & 0.36 \\
\hline d 29-56 & 0.81 & 0.95 & 1.05 & 0.72 & 0.17 & 0.34 & 0.06 & 0.76 \\
\hline Concentrate intake at weaning $(\mathrm{kg} / \mathrm{d})$ & 1.63 & 2.13 & 2.11 & 1.65 & 0.31 & 0.12 & 0.18 & 0.40 \\
\hline Feed efficiency (ADG/DMI) & 0.62 & 0.65 & 0.60 & 0.67 & 0.07 & 0.51 & 0.49 & 0.13 \\
\hline
\end{tabular}

${ }^{1}$ Dry-cow treatments: GSC = grass silage plus concentrate; GS = grass silage only.

${ }^{2} \mathrm{SED}=\mathrm{SE}$ of the difference.

${ }^{3} \mathrm{~N}=$ nutrition during dry period; $\mathrm{V}=$ volume of colostrum fed; $\mathrm{N} \times \mathrm{V}=$ interaction of nutrition and volume fed.

${ }^{4} \mathrm{ADG} / \mathrm{DMI}=$ average daily weight gain/average DMI (milk replacer + concentrate intake).

7). However, we observed no significant difference between treatment groups at weaning.

\section{$B W$ and BW Gain}

Concentrate supplementation and colostrum feeding regimen had no effect $(P>0.05)$ on $\mathrm{BW}$ or BW gain throughout the pre- and postweaning periods. However, we detected strong tendencies $(P=0.05)$ between $\mathrm{d} 0$ and 56 and $\mathrm{d} 0$ and 63 for calves in the $5 \mathrm{BW}$ group to perform better in terms of BW gain than calves in 10BW group (Table 8).

\section{Disease and IIIness}

Mortality rate $(2.7 \%)$ was low in this study, with only one calf dying during the experiment (treatment group GS-10BW). This calf died because of choking but no postmortem was carried out. Overall, independent of treatment, we observed a high morbidity rate of $73 \%$ during the experiment ( $73 \%$ of calves were treated for either diarrhea or pneumonia). Calves in the 5BW group had a greater $(P=0.003)$ fecal score and a greater percentage suffered from enteritis compared with calves in 10BW group (Table 9). A much greater percentage of calves from the 5BW group experienced multiple enteritis incidences $(27 \%)$ compared with calves from the 10BW group (5\%); $5 \%$ of the offspring in the GSC group had multiple incidences compared with $27 \%$ in the GS group. We observed no difference $(P>0.05)$ between colostrum treatment groups in terms of respiratory score and rate of pneumonia. However, calves from the GSC treatment group had a greater $(P=$ 0.04 ) average respiratory score and rate of pneumonia preweaning compared with calves in the GS treatment group.

We detected no differences $(P>0.05)$ between healthy and sick calves in terms of milk intake, drinking

Table 8. Effect of concentrate supplementation and colostrum feeding regimens on calf BW and BW daily gain from birth to 63 d of age

\begin{tabular}{|c|c|c|c|c|c|c|c|c|c|}
\hline \multirow[b]{2}{*}{ Item } & \multicolumn{2}{|c|}{ Dry-cow treatment $^{1}$} & \multirow[b]{2}{*}{$\mathrm{SED}^{2}$} & \multicolumn{2}{|c|}{ Colostrum treatment } & \multirow[b]{2}{*}{ SED } & \multicolumn{3}{|c|}{ Significance $^{3}$} \\
\hline & GSC & GS & & $5 \%$ of BW & $10 \%$ of $\mathrm{BW}$ & & $\mathrm{N}$ & $\mathrm{V}$ & $\mathrm{N} \times \mathrm{V}$ \\
\hline \multicolumn{10}{|l|}{ BW (kg) } \\
\hline $6-28 \mathrm{~d}$ & 47.0 & 46.8 & 0.85 & 46.80 & 47.0 & 0.62 & 0.71 & 0.69 & 0.58 \\
\hline $28-63 \mathrm{~d}$ & 63.6 & 64.8 & 1.56 & 65.40 & 63.0 & 1.54 & 0.48 & 0.19 & 0.68 \\
\hline $6-63 \mathrm{~d}$ & 57.3 & 57.9 & 1.46 & 58.20 & 57.0 & 1.17 & 0.62 & 0.56 & 0.83 \\
\hline \multicolumn{10}{|c|}{ BW gain $(\mathrm{kg} / \mathrm{d})$} \\
\hline $0-56 \mathrm{~d}$ & 0.54 & 0.57 & 0.04 & 0.59 & 0.51 & 0.04 & 0.26 & 0.05 & 0.83 \\
\hline $0-63 \mathrm{~d}$ & 0.58 & 0.59 & 0.04 & 0.62 & 0.54 & 0.04 & 0.56 & 0.05 & 0.88 \\
\hline
\end{tabular}

${ }^{1}$ Dry-cow treatments: GSC = grass silage plus concentrate; GS = grass silage only.

${ }^{2} \mathrm{SED}=\mathrm{SE}$ of the difference.

${ }^{3} \mathrm{~N}=$ nutrition during dry period; $\mathrm{V}=$ volume of colostrum fed; $\mathrm{N} \times \mathrm{V}=$ interaction of nutrition and volume fed. 
Table 9. Effect of concentrate supplementation and colostrum feeding regimens on mean health scores of calves

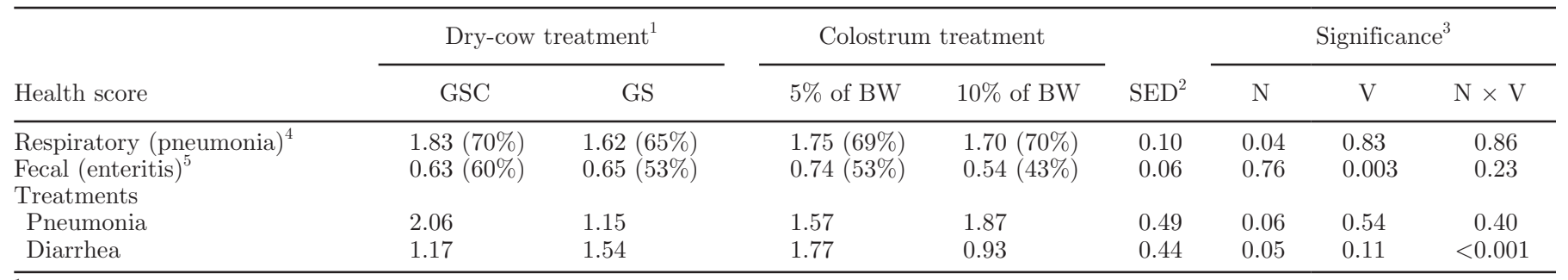

${ }^{1}$ Dry-cow treatments: GSC $=$ grass silage plus concentrate; GS = grass silage only.

${ }^{2} \mathrm{SED}=\mathrm{SE}$ of the difference.

${ }^{3} \mathrm{~N}=$ nutrition during dry period; $\mathrm{V}=$ volume of colostrum fed; $\mathrm{N} \times \mathrm{V}=$ interaction of nutrition and volume fed.

${ }^{4}$ Pneumonia occurs when a calf presents with a respiratory score $>5$ (\% of calves treated for pneumonia).

${ }^{5}$ Enteritis occurs when a calf presents with a fecal score of 3 or if it had a fecal score of 2 for 2 or more days (\% of calves treated for enteritis).

speed, or visits to the feeder with and without reward of milk replacer. However, sick days did have an effect $(P=0.002)$ on milk intake: we observed an increase in milk intake in the days following illness (Table 10). We found antibiotic treatment to have a negative effect $(P=0.04)$ on milk intake at $2 \mathrm{~d}$ following administration of antibiotic treatment. Antibiotic treatment also negatively affected calves' drinking speed $(P=0.007)$. Antibiotic treatment had no effect $(P>0.05)$ on the number of visits to the feeder with reward of milk replacer. However, antibiotic treatment had a negative effect on the number of visits without reward of milk replacer.

\section{DISCUSSION}

The rationale of this study was to determine the effect of concentrate supplementation during the dry period on colostrum quality and subsequent passive transfer of immunity on calf health and performance when calves were offered different levels of colostrum at birth.

We found no significant difference between maternal IgG concentration and time that colostrogenesis occurred precalving. In contrast, Herr et al. (2011) found a rapid decline in serum $\operatorname{IgG}$ levels beginning 8 and 4 wk before parturition, respectively, both reaching a nadir at parturition. Serum IgG levels did not recover until the fourth week after parturition. This correlated with findings from Guy et al. (1994) and Murphy et al. (2005), who examined $\operatorname{IgG}_{1}$ concentration pre- and postparturition in beef cows. The decrease in serum $\mathrm{IgG}_{1}$ concentrations prepartum, in association with colostrogenesis, is much greater in dairy (Guy et al., 1994) and beef $\times$ dairy (McGee et al., 2005, 2006) cows compared with beef breed cows, which implies that more $\operatorname{IgG}_{1}$ is transferred into the mammary secretion. This was confirmed by the significantly greater colostral $\operatorname{IgG}_{1}$ mass produced by these cow breed types (Guy et al., 1994; McGee et al., 2005) at first milking.
Concentrations of $\operatorname{IgG}_{2}$ generally increase in cow blood prepartum (Olson et al., 1981; McCutcheon et al., 1991; McGee et al., 2005). The reason for the differences observed between studies may be due to the assay used for quantification; in this study, we measured total IgG rather than specifically $\operatorname{IgG}_{1}$.

We found that supplementation with concentrate had a significant effect on maternal serum IgG concentration: cows in the GSC group had significantly greater serum IgG concentrations than those in the GS group. In this study, cows were provided with concentrate supplementation for 8 wk before parturition. Typically, rations provided during the early dry period are simple, often comprising a forage-based feed with a small amount of concentrate and a trace mineral salt. Such diets are fed for 4 to $6 \mathrm{wk}$ and cows are then introduced to a close-up ration to provide extra nutrients for the remaining weeks before parturition (Quigley and Drewry, 1998). To our knowledge, no information has been reported on this; therefore, this finding warrants further investigation. Feeding the cow supplementary concentrate during the dry period ( 8 wk before parturition) had no effect on colostrum IgG concentration, which was in agreement with previous findings (Blecha et al., 1981; Hough et al., 1990; Nowak et al., 2012). Concentrate supplementation had no effect on the nutritional composition (fat, lactose, and protein) of colostrum produced in the current study, which was comparable to reports from Quigley and Drewry (1998) and Nowak et al. (2012). In the current study, we observed that cows in the GSC group had greater colostrum yields in the first $8 \mathrm{~d}$ postpartum than cows from GS group. Colostrogenesis begins as early as $5 \mathrm{wk}$ before parturition (Brandon et al., 1971), and previous studies in sheep have shown that nutrition during the dry period can affect colostrum yield (O'Doherty and Crosby, 1996). In contrast, Duplessis et al. (2015) and Mann et al. (2016) reported no significant difference in colostrum yield at first milking from dairy cows when 


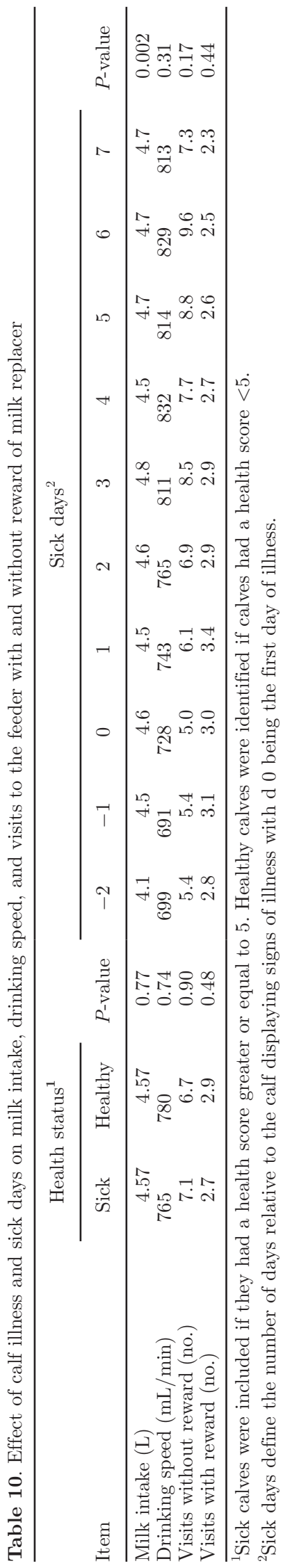

fed either a high- or low-energy diet during the dry period.

The mean $( \pm \mathrm{SE})$ IgG concentration of colostrum fed to all calves at their first feed was $54.4 \pm 3.72 \mathrm{mg} / \mathrm{mL}$. This was similar to the colostrum IgG concentration found in other studies (Gulliksen et al., 2008; Kehoe et al., 2011; Morrill et al., 2012), but much lower than that reported by Conneely et al. (2013). When comparing results, it is important to consider the laboratory method used to quantify immunoglobulins; Gelsinger et al. (2015) found a 50\% difference between IgG values measured by ELISA and by single radial immunodiffusion method.

In the current study, we established that colostrum IgG concentration declined rapidly after calving; this was similar to findings reported by Foley and Otterby (1978) and Blum and Hammon (2000). It has been well documented that calves should receive sufficient colostrum to achieve passive transfer of immunity (Weaver et al., 2000; Uruakpa et al., 2002; Godden, 2008). In the present study, serum IgG concentrations were greater in $10 \mathrm{BW}$ than in 5BW calves for the first $3 \mathrm{~d}$ after parturition. However, Conneely et al. (2014) reported that calves fed $8.5 \%$ of their BW in colostrum within $2 \mathrm{~h}$ of birth had greater serum IgG concentrations at 24, 48, and $72 \mathrm{~h}$ of age compared with calves fed 7 or $10 \%$ of their BW in colostrum. In the current study, the mean IgG concentration measured in calf sera at $12,24,48$, and $72 \mathrm{~h}$ of age, irrespective of treatment group, was $>10 \mathrm{mg} / \mathrm{mL}$. However, a significant proportion of these calves became sick, which may have been a consequence of all calves being group housed (suckling from one teat on an automatic feeder). Pneumonia and diarrhea are very contagious between animals and this may have encouraged transmission of disease (Johnson et al., 2011). At $24 \mathrm{~h}$ after birth, $13 \%$ of 5BW calves and $10 \%$ of $10 \mathrm{BW}$ calves had a serum IgG level $<10 \mathrm{mg} / \mathrm{mL}$. We determined that the large proportion of $5 \mathrm{BW}$ calves achieving passive transfer was due to the high-quality colostrum fed to this group and the time at which the calves received colostrum after birth. Nevertheless, $81 \%$ of calves in the 10BW group had a serum IgG level $>15$ $\mathrm{mg} / \mathrm{mL}$, and only $27 \%$ of the $5 \mathrm{BW}$ calves had serum IgG levels $>15 \mathrm{mg} / \mathrm{mL}$ at $24 \mathrm{~h}$ of age.

We found no treatment difference on AEA at $24 \mathrm{~h}$ after birth. In contrast, Conneely et al. (2014) found the mean AEA of calves fed $8.5 \%$ of $\mathrm{BW}$ in colostrum to be greater than that of calves fed $10 \%$ of their BW in colostrum at their first feed. Besser et al. (1985) suggested that this might be due to a negative correlation between mass of $\operatorname{IgG}_{1}$ fed and the calves' ability to absorb it into their bloodstream, which is further supported by Mokhber-Dezfooli et al. (2012). Stott et al. (1979) suggested that $2 \mathrm{~L}$ of colostrum should be 
fed to Holstein calves to achieve maximum pinocytotic activation of absorptive cells and the greatest rate of absorption. In agreement, Jaster (2005) found that calves fed $2 \mathrm{~L}$ at birth and $2 \mathrm{~L}$ at $12 \mathrm{~h}$ compared with $4 \mathrm{~L}$ at birth had greater serum IgG concentrations. In the present study, AEA was not affected by concentrate supplementation during the dry period, which was supported by Halliday et al. (1978). However, data from beef calves suggest that absorption of IgG may be impaired when low protein diets are fed during the dry period (Hough et al., 1990). Moreover, recent findings have shown that calves exposed to heat stress when in utero also have reduced AEA (Tao et al., 2012).

Concentrate supplementation during the dry period did not affect the calves' birth weight, which is supported by findings from Budge et al. (2004), in which it was suggested that there has to be a strict and drawnout reduction in maternal feed intake to compromise the weight of the newborn calf. No significant differences in BW gain were found between calves from cows fed different preparturient diets. In contrast, Martin et al. (2007) reported that heifer calves born to cows that received $0.45 \mathrm{~kg} / \mathrm{d}$ of a $42 \% \mathrm{CP}$ supplement in late gestation were heavier at weaning than offspring from nonsupplemented dams. Colostrum feeding regimen had no significant effect on calf BW or daily BW gain. However, between d 0 and 56 and d 0 and 63 , a trend $(P=0.05)$ showed calves from 5BW group to have a greater BW gain than those in 10BW, perhaps due to their increased concentrate intake. In contrast, Faber et al. (2005) found that calves fed $4 \mathrm{~L}$ of colostrum compared with $2 \mathrm{~L}$ at their first feed had greater BW gain in the first $500 \mathrm{~d}$ of life. However, Krohn et al. (1999) found no difference in BW gain for calves offered 3 different colostrum treatments; the first group of calves were in a single box and had no contact with the dam, the second group allowed the cow and calf to be together but no suckling, and the third group allowed the cow and calf together and suckling. In the present study, we observed no difference between colostrum treatment groups and feed efficiency; to date, there is a dearth of literature available and this finding requires further investigation. In our study, calves were offered a restricted volume of milk replacer and there was no significant difference between treatment groups in volume of milk replacer consumed. The growth and antimicrobial factors found in colostrum may have a role in the efficiency and development of the dairy calf in terms of nutrition (Pakkanen and Aalto, 1997).

Concentrate supplementation and colostrum feeding regimen had no effect on milk replacer consumed in the preweaning period, which is in agreement with the findings of Quigley et al. (1995). In the current study, calves in the 5BW group had greater concentrate intake during the preweaning period than calves in the 10BW group. Further research is required to investigate the effects of colostrum feeding regimens on gut health and development. However, we observed no significant difference between treatment groups after weaning when they were offered ad libitum concentrate until d 63 . We found no difference in concentrate intake between dry-cow treatment groups. In the literature, there is a paucity of studies demonstrating the direct effects of maternal nutrition on feed intake of offspring, and further research is needed in this area.

Mortality rate in the current study was low compared with that in a study conducted in the United States, where the overall mortality was $3.5 \%$ (Windeyer et al., $2014)$, and in a Swedish study (3.1\%; Svensson et al., 2006). However, the number of calves treated for enteritis and BRD was high in the current study $(52.3 \%$, $68.5 \%$ ) compared with Windeyer et al. (2014), in which almost $22 \%$ of calves were treated at least once for BRD and $23 \%$ were treated for diarrhea. Torsein et al. (2011) also showed a positive association between diarrhea and poor passive transfer via colostrum. Consequently, good colostrum management is considered a vital element of the management of enteric disease (McGuirk, 2008). Compared with findings from the current study, Virtala et al. (1996) observed no apparent difference in IgG between BRD cases and controls. The high level of morbidity observed in the current study may be a result of group housing and consequent increased spread of disease between animals. This is in accordance with previous studies (Waltner-Toews et al., 1986; Virtala et al., 1999), which showed use of calf hutches to be associated with a lower incidence of BRD than other types of group housing. In addition to passive transfer status, it is important to recognize the overall existing farm issues to create prevention protocols to advance husbandry, vaccination, and hygiene strategies with the overall aim to reduce morbidity.

Calf ill health showed no significant differences between rewarded and unrewarded visits to the feeder; however, calves given antibiotics had a decrease in the number of visits without reward of milk replacer. This is in agreement with findings from Johnson et al. (2011), who reported that the routine use of antibiotics to treat calf diarrhea was linked to negative outcomes, and such use is therefore actively discouraged. Svensson and Jensen (2007) reported a significant difference between healthy and diseased animals $(P<0.01)$ such that healthy and diseased calves visited the feeder on 20 and 16 occasions, respectively, over a 24 -h period. These findings are in agreement with Sowell et al. (1999), who demonstrated the feeding behavior of 
group-housed steers. Borderas et al. (2009) reported that feed allowance affects feeding behavior associated with illness of milk-fed calves. In our study, calves were closely monitored and medical treatment was administered very quickly. If these calves had not been treated so promptly, we might have detected a difference. In the present study, we observed a reduction in drinking speed in calves with diarrhea or high rectal temperature and in calves given antibiotics. This corresponds with findings from Borderas et al. (2009), who reported that sick calves take longer to consume a smaller meal compared with healthy calves. Maatje et al. (1993) determined a decline in drinking speed to be a dependable indicator of ill health in calves. In contrast, Svensson and Jensen (2007) found no difference in drinking speed between healthy and diseased calves.

In the current study, we observed that offspring of cows in the GS group had greater rates of enteritis than offspring of cows in the GSC group. This is supported by Corah et al. (1975), who found a greater incidence of diarrhea in beef calves from cows that were offered a low-energy diet during the dry period compared with a high-energy diet. Funston et al. (2010) suggest that supplementation of concentrate to cows during the dry period provides the cow with nonstructural carbohydrates that are fermented to propionate in the rumen and transformed into glucose. Glucose is crucial for growth and development of the fetus (Funston et al., 2010). Therefore, it is possible that concentrate supplementation of the cow during the dry period is beneficial to fetus development. Wu et al. (2006) and Schoonmaker and Eastridge (2013) reported the importance of nutritional conditions during critical stages in fetus development in terms of long-term health issues and growth of the calf.

In the present study, the rate of enteritis was greater for $5 \mathrm{BW}$ calves than for $10 \mathrm{BW}$ calves. We believe that this may be due to the increased serum IgG concentration in calves during the first $3 \mathrm{~d}$ of life in 10BW calves compared with 5BW calves, and this is supported by Waldner and Rosengren (2009). This is comparable to previous research in which calves fed high-quality colostrum had less severe diarrhea of lesser duration compared with calves fed low-quality colostrum (Nocek et al., 1984). Relative to this, Faber et al. (2005) reported that calves fed $2 \mathrm{~L}$ compared with $4 \mathrm{~L}$ of colostrum at birth were at higher risk of disease. Reducing ill health early in life is important because calves that experience episodes of ill health have reduced growth (Donovan et al., 1998), reproduction (Correa et al., 1988; FurmanFratczak et al., 2011), and milking performance (Heinrichs and Heinrichs, 2011), and increased veterinary costs (Faber et al., 2005).

\section{CONCLUSIONS}

Concentrate supplementation during the $8 \mathrm{wk}$ before parturition had no effect on colostral IgG concentration, IgG yield, or fat, protein, and lactose contents. However, cows fed concentrate produced a greater yield of colostrum at birth and for the first 8 milkings postpartum. Concentrate supplementation had no effect on calf serum IgG concentration but did affect the rate of pneumonia, whereby offspring from cows in the GSC group had 10\% more pneumonia cases than the GS treatment group.. Feeding Holstein dairy calves 10\% of their BW in colostrum at birth resulted in a greater IgG concentration in the calves' serum for the first 3 d postpartum compared with feeding only $5 \%$ of BW in colostrum. Calves had reduced rates of enteritis and medical treatments if they were fed $10 \%$ compared with $5 \%$ of their BW in colostrum at their first feeding after birth. Further research is necessary to investigate the potential effect of various dry-cow feeding strategies on colostrogenesis, fetal programming, gut maturation, and metabolism of the newborn calf. Overall, to achieve successful passive transfer, reduce rates of enteritis, and increased efficiency in the dairy calf, we recommend that dairy calves be fed $10 \%$ of their BW in colostrum as soon as possible after birth.

\section{ACKNOWLEDGMENTS}

This study was co-funded by the Department of Agriculture and Rural Development in Northern Ireland, Department of Agriculture, Food and Marine, Ireland [DAFM; Research Stimulus Fund (11/S/131) to B. Earley]; and by AgriSearch (farmer levy). Thanks are due to the Dairy and Calf Unit staff at the AFBI Hillsborough for care of the experimental animals and for assisting with experimental measurements, the laboratory staff in AFBI Hillsborough for undertaking milk and feed analysis, and to the staff in AFBI Veterinary Sciences Division for assisting with blood analysis. Amanda Dunn acknowledges the receipt of a PhD studentship from AgriSearch.

\section{REFERENCES}

AFBI-DAFM (Agri-Food and Biosciences Institute, and Department of Food and Marine). 2013. All-island animal disease surveillance report: A joint AFBI/DAFM Veterinary Laboratories Publication. Northern Ireland and Ireland.

Agnew, R. E., T. Yan, J. France, E. Kebreab, and C. Thomas. 2004. Feed into Milk. A New Applied Feeding System for Dairy Cows. Nottingham University Press, Nottingham, UK.

Barrington, G. M., and S. M. Parish. 2001. Bovine neonatal immunology. Vet. Clin. North Am. Food Anim. Pract. 17:463-476.

Besser, T. E., A. E. Garmedia, T. C. McGuire, and C. C. Gay. 1985. Effect of colostral immunoglobulin G1 and immunoglobulin M 
concentrations on immunoglobulin absorption in calves. J. Dairy Sci. 68:2033-2037.

Blecha, F., R. C. Bull, D. P. Olson, R. H. Ross, and S. Curtis. 1981. Effects of prepartum protein restriction in the beef cow on immunoglobin content in blood and colostral whey and subsequent immunoglobin absorption by the neonatal calf. J. Anim. Sci. $53: 1174-1180$

Blum, J. W., and H. Hammon. 2000. Colostrum effects on the gastrointestinal tract, and on nutritional, endocrine and metabolic parameters in neonatal calves. Livest. Sci. 66:151-159.

Borderas, T. F., J. Rushen, M. A. G. von Keyserlingk, and A. M. B. de Passillé. 2009. Automated measurement of changes in feeding behavior of milk-fed calves associated with illness. J. Dairy Sci. 92:4549-4554.

Brandon, M. R., D. L. Watson, and A. K. Lascelles. 1971. The mechanism of transfer of immunoglobulin into mammary secretion of cows. Aust. J. Exp. Biol. Med. Sci. 49:613-623.

Budge, H., L. J. Edwards, I. C. McMillen, A. Bryce, K. Warnes, S. Pearce, T. Stephenson, and M. E. Symonds. 2004. Nutritional manipulation of fetal adipose tissue deposition and uncoupling protein 1 messenger RNA abundance in the sheep: Differential effects of timing and duration. Biol. Reprod. 71:359-365.

Chigerwe, M., J. W. Tyler, L. G. Schultz, J. R. Middleton, B. J. Steevens, and J. N. Spain. 2008. Effect of colostrum administration by use of oresophageal intubation on serum IgG concentrations in Holstein bull calves. Am. J. Vet. Res. 69:1158-1163.

Chua, B., E. Coenen, J. van Delen, and D. M. Weary. 2002. Effects of pair versus individual housing on the behaviour and performance of dairy calves. J. Dairy Sci. 85:360-364.

Clark, D. S. 1967. Comparison of pour and surface plate methods for determination of bacterial counts. Can. J. Microbiol. 13:1409-1412.

Conneely, M., D. P. Berry, J. P. Murphy, I. Lorenz, M. L. Doherty, and E. Kennedy. 2014. Effect of feeding colostrum at different volumes and subsequent number of transition milk feeds on the serum immunoglobulin $\mathrm{G}$ concentration and health status of dairy calves. J. Dairy Sci. 97:6991-7000.

Conneely, M., D. P. Berry, R. Sayers, J. P. Murphy, I. Lorenz, M. L. Doherty, and E. Kennedy. 2013. Factors associated with the concentration of immunoglobulin $\mathrm{G}$ in the colostrum of dairy cows. Animal 7:1824-1832.

Corah, L. R., T. G. Dunn, and C. C. Kaltenbach. 1975. Influence of prepartum nutrition on the reproductive performance of beef females and the performance of their progeny. J. Anim. Sci. 41:819 824

Correa, M. T., C. R. Curtis, H. N. Erb, and M. E. White. 1988. Effect of calfhood morbidity on age at first calving in New York Holstein herds. Prev. Vet. Med. 6:253-262.

Cushnahan, A., and F. Gordon. 1995. The effects of grass preservation on intake, apparent digestibility and rumen degradation characteristics. Anim. Sci. 60:429-438.

Donovan, G. A., I. R. Dohoo, D. M. Montgomery, and F. L. Bennett. 1998. Calf and disease factors affecting growth in female Holstein calves in Florida, USA. Prev. Vet. Med. 33:1-10.

Duplessis, M., S. Mann, D. V. Nydam, C. L. Girard, D. Pellerin, and T. R. Overton. 2015. Short communication: Folates and vitamin B12 in colostrum and milk from dairy cows fed different energy levels during the dry period. J. Dairy Sci. 98:5454-5459.

Faber, S., N. Faber, T. McCauley, and R. Ax. 2005. Case study: Effects of colostrum ingestion on lactational performance. Prof. Anim. Sci. 21:420-425.

Foley, J., and D. Otterby. 1978. Availability, storage, treatment, composition, and feeding value of surplus colostrum: A review. J. Dairy Sci. 61:1033-1060.

Funston, R. N., D. M. Larson, and K. Vonnahme. 2010. Effects of maternal nutrition on conceptus growth and offspring performance: Implications for beef cattle production. J. Anim. Sci. 88:E205E215.

Furman-Fratczak, K., A. Rzasa, and T. Stefaniak. 2011. The influence of colostral immunoglobulin concentration in heifer calves' serum on their health and growth. J. Dairy Sci. 94:5536-5543.
Gelsinger, S. L., A. M. Smith, C. M. Jones, and A. J. Heinrichs. 2015. Technical note: Comparison of radial immunodiffusion and ELISA for quantification of bovine immunoglobulin $\mathrm{G}$ in colostrum and plasma. J. Dairy Sci. 98:4084-4089.

Godden, S. 2008. Colostrum management for dairy calves. Vet. Clin. North Am. Food Anim. Pract. 24:19-39.

Gulliksen, S. M., K. I. Lie, L. Sølverød, and O. Østerås. 2008. Risk factors associated with colostrum quality in Norwegian dairy cows. J. Dairy Sci. 91:704-712.

Guy, M. A., T. B. McFadden, D. C. Cockrell, and T. E. Besser. 1994. Regulation of colostrum formation in beef and dairy cows. J. Dairy Sci. 77:3002-3007.

Halliday, R., A. J. Russel, M. R. Williams, and J. N. Peart. 1978. Effects of energy intake during late pregnancy and of genotype on immunoglobulin transfer to calves in suckler herds. Res. Vet. Sci. $24: 26-31$

Hanuš, O., P. Roubal, J. Ř́ha, M. Vyletělová Klimešová, E. Samková, R. Jedelská, and J. Kopecký. 2014. Development in indirect infrared determination of milk acetone. Acta Univ. Agric. Silvic. Mendel. Brun. 62:919-927.

Heinrichs, A. J., and B. S. Heinrichs. 2011. A prospective study of calf factors affecting first-lactation and lifetime milk production and age of cows when removed from the herd. J. Dairy Sci. 94:336-341.

Herr, M., H. Bostedt, and K. Failing. 2011. IgG and IgM levels in dairy cows during the periparturient period. Theriogenology 75:377-385.

Hough, R. L., F. D. McCarthy, H. D. Kent, D. E. Eversole, and M. L. Wahlberg. 1990. Influence of nutritional restriction during late gestation on production measures and passive immunity in beef cattle. J. Anim. Sci. 68:2622-2627.

Jaster, E. H. 2005. Evaluation of quality, quantity, and timing of colostrum feeding on immunoglobulin G1 absorption in Jersey calves. J. Dairy Sci. 88:296-302.

Johnson, K., C. C. Burn, and C. C. Wathes. 2011. Rates and risk factors for contagious disease and mortality in young dairy heifers. Anim. Sci. Rev. 205:101-113.

Kehoe, S. I., A. J. Heinrichs, M. L. Moody, C. M. Jones, and M. R. Long. 2011. Comparison of immunoglobulin G concentrations in primiparous and multiparous bovine colostrum. Prof. Anim. Sci. $27: 176-180$

Krohn, C. C., J. Foldager, and L. Mogensen. 1999. Long-term effect of colostrum feeding methods on behaviour in female dairy calves. Acta Agric. Scand. A Anim. Sci. 49:57-64.

Little, M. W., N. E. O'Connell, M. D. Welsh, J. Barley, K. G. Meade, and C. P. Ferris. 2016. Prepartum concentrate supplementation of a diet based on medium quality grass silage: Effects on performance, health, fertility, metabolic function, and immune function of low body condition score cows. J. Dairy Sci. 99:7102-7122.

Logue, D. N., and C. Mayne. 2014. Welfare-positive management and nutrition for the dairy herd: A European perspective. Vet. J. 199:31-38.

Lorenz, I., J. F. Mee, B. Earley, and S. J. More. 2011. Calf health from birth to weaning. I. General aspects of disease prevention. Ir. Vet. J. 64:10.

Maatje, K., J. Verhoeff, W. D. Kremer, A. L. Cruijsen, and T. S. van den Ingh. 1993. Automated feeding of milk replacer and health control of group-housed veal calves. Vet. Rec. 133:266-270.

Mann, S., F. A. L. Yepes, T. R. Overton, A. L. Lock, S. V. Lamb, J. J. Wakshlag, and D. V. Nydam. 2016. Effect of dry period dietary energy level in dairy cattle on volume, concentration of immunoglobulin G, insulin, and fatty acid composition of colostrum. J. Dairy Sci. 99:1515-1526.

Martin, J. L., K. A. Vonnahme, D. C. Adams, G. P. Lardy, and R. N. Funston. 2007. Effects of dam nutrition on growth and reproductive performance of heifer calves. J. Anim. Sci. 85:841-847.

McCutcheon, G. A., P. J. McCaffrey, D. L. Kelleher, and P. O. Brophy. 1991. Twinning in a suckler herd: 2. Effects on cow and calf immunoglobulin status. Isr. J. Agric. Res. 30:11-17.

McGee, M., M. J. Drennan, and P. J. Caffery. 2005. Effect of suckler cow genotype on cow serum immunoglobulin (Ig) levels, colostrum yield, composition and Ig concentration and subsequent immune status of their progeny. Ir. J. Agric. Food Res. 44:173-183. 
McGee, M., M. J. Drennan, and P. J. Caffery. 2006. Effect of age and nutrient restriction pre partum on beef suckler cow serum immunoglobulin concentrations, colostrum yields, composition and immunoglobulin concentration and immune status of their progeny. Ir. J. Agric. Food Res. 45:157-171.

McGuirk, S. M. 2008. Disease management of dairy calves and heifers. Vet. Clin. North Am. Food Anim. Pract. 24:139-153.

McGuirk, S. M., and M. Collins. 2004. Managing the production, storage and delivery of colostrum. Vet. Clin. North Am. Food Anim. Pract. 20:593-603.

McGuirk, S. M., and S. F. Peek. 2014. Timely diagnosis of dairy calf respiratory disease using a standardized scoring system. Anim. Health Res. Rev. 15:145-147.

Mokhber-Dezfooli, M. R., M. Nouri, M. Rasekh, and P. D. Constable. 2012. Effect of abomasal emptying rate on the apparent efficiency of colostral immunoglobulin G absorption in neonatal HolsteinFriesian calves. J. Dairy Sci. 95:6740-6749.

Morrill, K. M., E. Conrad, A. Lago, J. Campbell, J. Quigley, and H. Tyler. 2012. Nationwide evaluation of quality and composition of colostrum on dairy farms in the United States. J. Dairy Sci. 95:3997-4005.

Murphy, B. M., M. J. Drennan, F. P. O'Mara, and B. Earley. 2005. Cow serum and colostrum immunoglobulin (IgG1) concentration of five suckler cow breed types and subsequent immune status of their calves. Ir. J. Agric. Food Res. 44:205-213.

Nocek, J. E., D. G. Braund, and R. G. Warner. 1984. Influence of neonatal colostrum administration, immunoglobulin, and continued feeding of colostrum on calf gain, health, and serum protein. J. Dairy Sci. 67:319-333.

Nowak, W., R. Mikula, A. Zachwieja, K. Paczynska, E. Pecka, K. Drzazga, and P. Slosarz. 2012. The impact of cow nutrition in the dry period on colostrum quality and immune status of calves. Pol. J. Vet. Sci. 15:77-82.

O'Doherty, J. V., and T. F. Crosby. 1996. The effect of diet in late pregnancy on progesterone concentration and colostrum yield in ewes. Theriogenology 46:233-241.

Olsen, D. P., R. C. Bull, L. F. Woodard, and K. W. Kelley. 1981. Effects of maternal nutritional restriction and cold stress on young calves-Absorption of colostral immunoglobulins. Am. J. Vet. Res. $42: 876-880$.

Pakkanen, R., and J. Aalto. 1997. Growth factors and antimicrobial factors of bovine colostrum. Int. Dairy J. 7:285-297.

Park, R. S., R. E. Agnew, F. J. Gordon, and R. W. J. Steen. 1998. The use of near infrared reflectance spectroscopy (NIRS) on undried samples of grass silage to predict chemical composition and digestibility parameters. Anim. Feed Sci. Technol. 72:155-167.

Porter, M. 1992. Comparison of sample preparation methods for the determination of the gross energy concentration of fresh silage. Anim. Feed Sci. Technol. 37:201-208.

Porter, M. G., and R. S. Murray. 2001. The volatility of components of grass silage on oven drying and the inter-relationship between drymatter content estimated by different analytical methods. Grass Forage Sci. 56:405-411

Quigley, J. D., 3rd, and J. J. Drewry. 1998. Nutrient and immunity transfer from cow to calf pre and postcalving. J. Dairy Sci. 81:2779-2790

Quigley, J. D., 3rd, J. J. Drewry, and K. R. Martin. 1998. Estimation of plasma volume in Holstein and Jersey calves. J. Dairy Sci. 81:1308-1312.

Quigley, J. D., K. Martin, D. A. Bemis, L. Potgieter, C. R. Reinemeyer, B. Rohrbach, H. Dowlen, and K. Lamar. 1995. Effects of housing and colostrum feeding on serum immunoglobulins, growth, and fecal scores of Jersey calves. J. Dairy Sci. 78:893-901.

Quigley, J. D., 3rd, C. J. Kost, and T. M. Wolfe. 2002. Absorption of protein and IgG in calves fed a colostrum supplement or replacer. J. Dairy Sci. 85:1243-1248.

Schoonmaker, J., and M. Eastridge. 2013. Effect of maternal nutrition on calf health and growth. Pages 63-80 in Proc. Tri-State Dairy Nutrition. Ohio State and Michigan State University, Fort Wayne, IN

Sowell, B. F., M. Branine, J. Bowman, M. Hubbert, H. Sherwood, and W. Quimby. 1999. Feeding and watering behavior of healthy and morbid steers in a commercial feedlot. J. Anim. Sci. 77:1105-1112.

Spielman, A. A., J. W. Thomas, J. K. Loosli, C. L. Norton, and K. L. Turk. 1946. The placental transmission and fetal storage of vitamin A and carotene in the bovine. J. Dairy Sci. 29:707-715.

Steen, R. 1989. A comparison of soya-bean, sunflower and fish meals as protein supplements for yearling cattle offered grass silage-based diets. Anim. Prod. 48:81-89.

Stott, G. H., D. B. Marx, B. E. Menefee, and G. T. Nightengale. 1979. Colostral immunoglobulin transfer in calves: II. The rate of absorption. J. Dairy Sci. 62:1766-1773.

Svensson, C., and M. B. Jensen. 2007. Short communication: Identification of diseased calves by use of data from automatic milk feeders. J. Dairy Sci. 90:994-997.

Svensson, C., A. Linder, and S. O. Olsson. 2006. Mortality in Swedish dairy calves and replacement heifers. J. Dairy Sci. 89:4769-4777.

Tao, S., A. P. A. Monteiro, I. M. Thompson, M. J. Hayen, and G. E. Dahl. 2012. Effect of late-gestation maternal heat stress on growth and immune function of dairy calves. J. Dairy Sci. 95:7128-7136.

Torsein, M., A. Lindberg, C. H. Sandgren, K. P. Waller, M. Tornquist, and C. Svensson. 2011. Risk factors of calf mortality in large Swedish dairy herds. Prev. Vet. Med. 99:136-147.

Uruakpa, F. O., M. A. H. Ismond, and E. N. T. Akobundu. 2002. Colostrum and its benefits: A review. Nutr. Res. 22:755-767.

Virtala, A. M., Y. T. Grohn, G. D. Mechor, and H. N. Erb. 1999. The effect of maternally derived immunoglobulin $\mathrm{G}$ on the risk of respiratory disease in heifers during the first three months of life. Prev. Vet. Med. 39:25-37.

Virtala, A. M. K., G. D. Mechor, Y. T. Grohn, H. N. Erb, and E. J. Dubovi. 1996. Epidemiologic and pathologic characteristics of respiratory tract disease in dairy heifers during the first three months of life. J. Am. Vet. Med. Assoc. 208:2035-2042.

Waldner, C. L., and L. B. Rosengren. 2009. Factors associated with serum immunoglobulin levels in beef calves from Alberta and Saskatchewan and association between passive transfer and health outcomes. Can. Vet. J. 50:275-281.

Waltner-Toews, D., S. W. Martin, and A. H. Meek. 1986. Dairy calf management, morbidity and mortality in Ontario Holstein herds. III. Association of management with morbidity. Prev. Vet. Med. 4:137-158.

Weaver, D. M., J. W. Tyler, D. C. VanMetre, D. E. Hostetler, and G. M. Barrington. 2000. Passive transfer of colostral immunoglobulins in calves. J. Vet. Intern. Med. 14:569-577.

Windeyer, M. C., K. E. Leslie, S. M. Godden, D. C. Hodgin, K. D. Lissemore, and S. J. LeBlanc. 2014. Factors associated with morbidity, mortality, and growth of dairy heifer calves up to 3 months of age. Prev. Vet. Med. 113:231-240.

Wu, G., F. W. Bazer, J. M. Wallace, and T. E. Spencer. 2006. Boardinvited review: Intrauterine growth retardation: Implications for the animal sciences. J. Anim. Sci. 84:2316-2337. 